\title{
COMUNICAÇÃO
}

\section{TOXOPLASMA GONDII NA MUCOSA GÁSTRICA COMO PRIMEIRO ACHADO EM PACIENTE AIDÉTICO}

\author{
Filomena Rita C. Florêncio, Francisco B. Albuquerque Filho e Mário A. P. Moraes
}

O parasitismo por Toxoplasma gondii é muito difundido, porém, a despeito da alta frequência da infecção em seres humanos, são raras as pessoas infectadas que exibem manifestacões clínicas. $\mathrm{Na}$ maioria dos casos, após a infecção primária - quase sempre assintomática ou de duração variável,$- T$. gondii passa ao estado de vida latente, dentro dos tecidos do hospedeiro. As formas correspondentes, os bradizoítos, são encontradas em cistos, no interior de várias células, particularmente as dos músculos esqueléticos, miocárdio e cérebro. Recrudescência da infecção pode ocorrer em pacientes imunodeprimidos ou com a síndrome da imunodeficiência adquirida (AIDS). A maioria dos pacientes nessas condicões sucumbe de encefalite grave, enquanto alguns desenvolvem coriorretinite ou miocardite ${ }^{1}$. O número de microrganismos ou taquizoítos - elementos de multiplicação rápida - é neles muito grande e tem origem provavelmente em bradizoítos provenientes

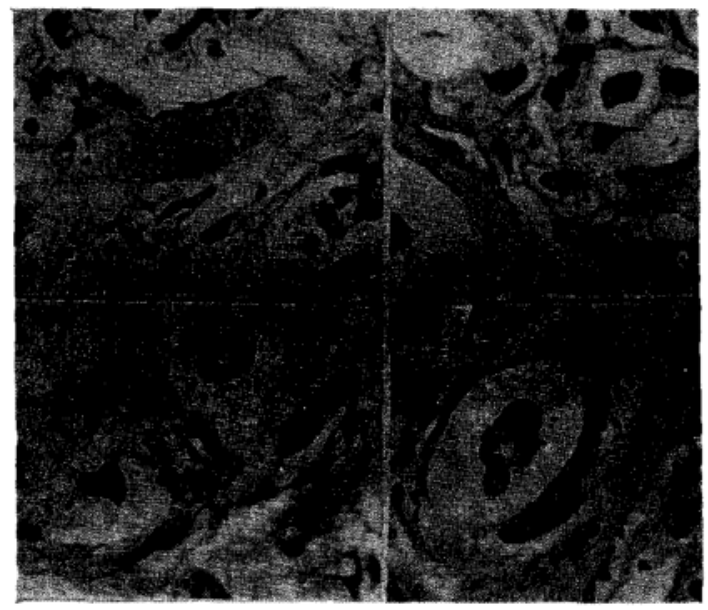

Figura 1 - À esquerda, cistos com bradizoítos (PAS positivos). $800 x$ e 1.000x; à direita, taquizoítos dentro de vacúolos. $800 x$.

Hospital Regional do Gama da Fundação Hospitalar do Distrito Federal Gama, DF e Universidade de Brasília, Brasília, DF.

Endereço para correspondência: Dr. Mário A. P. Moraes. FS/PTL/UnB. CP: 15-3031, 70910-900 Brasilia, DF.

Recebido para publicação em 09/04/92 dos cistos que então se abrem, devido à queda na imunidade.

A presente comunicação refere-se ao caso de um homem jovem, aidético, com toxoplasmose aguda, sem alteracões neurológicas, cuja infecção pelo HIV só foi descoberta após o achado do toxoplasma na mucosa do estômago, através de biópsia endoscópica, um registro incomum.

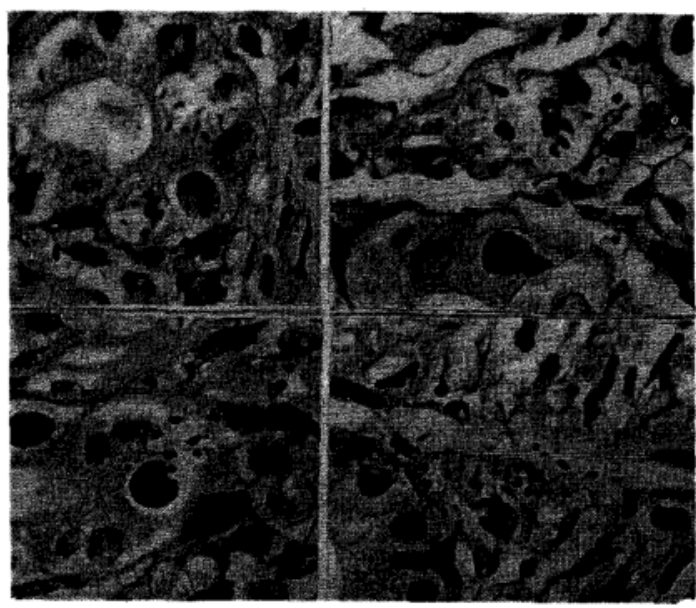

Figura 2 - Taquizoítos em vacúolos intracelulares nas glândulas do estômago, alguns já em fase de liberação. $800 x$.

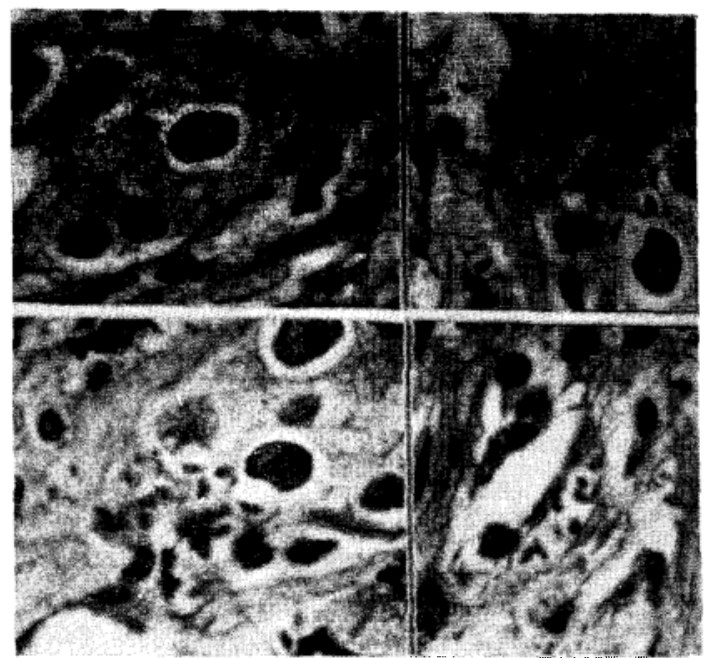

Figura 3 - Taquizoítos aparentemente já livres nos tecidos. $800 x$. 
Comunicação. Florêncio FRC, Albuquerque Filho FB, Moraes MAP. Toxoplasma gondii na mucosa gástrica como primeiro achado em paciente aidético. Revista da Sociedade Brasileira de Medicina Tropical 25:275-276, out-dez, 1992.

Descrição do caso. M.O.S., 34 anos, natural da Bahia e procedente da Cidade Ocidental, Estado de Goiás; veio à consulta no Hospital Regional do Gama, DF, em janeiro de 1992, com queixa de dor no epigástrio, diarréia e crises de vômitos. Referiu hepatite viral há dois anos e tratamento para tuberculose pulmonar em época mais recente. A endoscopia do estômago revelou na mucosa uma lesão ulcerada, de cuja borda tomou-se uma biópsia. Microscopicamente, alterações celulares sugestiuvas de displasia, foram encontradas nas glândulas gástricas. Com forte aumento, no entanto, grupos de microrganismos, crescentiformes e medindo 3 a $5 \mu \mathrm{m}$ de comprimento, podiam ser vistos dentro de vacúolos intracelulares em muitas das células glandulares. Algumas destas células pareciam já rotas e no ato de liberação dos microrganismos identificados como taquizoítos de $T$. gondii. Raros cistos, repletos de elementos PAS-positivos (bradizoítos), foram também descobertos nos cortes. Após confirmar-se pelo ELISA estar o paciente infectado pelo HIV, conseguiu-se apurar ser ele homossexual ejá ter apresentado infecções repetidas dos tratos urinário e respiratório (estas atribuídas ao fato de trabalhar ele em câmara fria). Ao ser visto novamente, decorridas algumas semanas de endoscopia, achava-se o paciente em estado precário, inclusive com candidíase oral; soube-se ter ele falecido poucos dias depois.

\section{REFERÊNCIA BIBLIOGRÁFICA}

Frenkel JK. Toxoplasmosis in human beings. Journal of the American Veterinary Medical Association 196:240248, 1990. 